\title{
TAX MANAGEMENT LEARNING MODEL USING E-INVOICE METHOD
}

\author{
Fitriani Saragih ${ }^{1}$, Zulia Hanum ${ }^{2}$, Jasman Saripuddin Hsb $^{3}$ \\ Faculty of Economics and Business, Universitas Muhammadiyah Sumatera Utara \\ Email: fitriani@umsu.ac.id
}

\begin{abstract}
To facilitate the preparation of tax reports, namely providing information to the parties in need that will be used to make comparisons, assess the ability of a company, as well as as a guide for decision making. In order to fulfill the above objectives, tax reports must be comparable. These comparisons can be made in two ways, namely horizontally and vertically. Horizontal comparison is a comparison of a company's tax report with other companies for the same period, which in concept can be easily made if the preparation uses an existing software. This study aims to develop a taxation learning model by using the E-Faktur program as teaching material for lecture materials at universities. The specific target to be achieved in this research is to issue teaching materials in the form of tax books compiled with the E-Faktur program. To achieve this goal, this study uses descriptive analysis to identify the problems that exist in taxation learning at universities at the Muhammadiyah University of North Sumatra (UMSU) in Medan City which has been running so far. These problems include not understanding students in using the E-Faktur program which has been issued for a long time, and not being motivated to study the program due to lack of guidance in carrying out the practice. To find the factors that become obstacles in understanding the use of the program. By identifying these factors, Furthermore, a teaching material can be arranged to motivate students to want to enjoy the teaching material and the goal of educating the nation's children can be achieved. This research was conducted on North Sumatra Muhammadiyah University students who took the 6th semester tax management course for the 2018-2019 academic year. The sample in this study was 90 people. Because of the number of questionnaires that were returned only 90 . Based on the data on the questionnaire that has been distributed by the researchers to 90 respondents, obtained data regarding the general description of the research respondents. In this study, the number of female respondents was more, namely 68 people or $75.6 \%$, when compared to male respondents, namely as many as 22 people or $24.4 \%$. This shows that on average the respondents at the Muhammadiyah University of North Sumatra are women. This research was conducted on North Sumatra Muhammadiyah University students who took the 6th semester tax management course for the 2018-2019 academic year. The sample in this study was 90 people. Because of the number of questionnaires that were returned only 90 . Based on the data on the questionnaire that has been distributed by the researchers to 90 respondents, obtained data regarding the general description of the research respondents. In this study, the number of female respondents was more, namely 68 people or $75.6 \%$, when compared to male respondents, namely as many as 22 people or $24.4 \%$. This shows that on average the respondents at the Muhammadiyah University of North Sumatra are women. This research was conducted on North Sumatra Muhammadiyah University students who took the 6th semester tax management course for the 2018-2019 academic year. The sample in this study was 90 people. Because of the number of questionnaires that were returned only 90 . Based on the data on the questionnaire that has been distributed by the researchers to 90 respondents, obtained data regarding the general description of the research respondents. In this study, the number of female respondents was more, namely 68
\end{abstract}


people or $75.6 \%$, when compared to male respondents, namely as many as 22 people or $24.4 \%$. This shows that on average the respondents at the Muhammadiyah University of North Sumatra are women. Based on the data on the questionnaire that has been distributed by the researcher to 90 respondents, data is obtained regarding the general description of the research respondents. In this study, the number of female respondents was more, namely 68 people or $75.6 \%$, when compared to male respondents, namely as many as 22 people or $24.4 \%$. This shows that on average the respondents at the Muhammadiyah University of North Sumatra are women. Based on the data on the questionnaire that has been distributed by the researcher to 90 respondents, data is obtained regarding the general description of the research respondents. In this study, the number of female respondents was more, namely 68 people or $75.6 \%$, when compared to male respondents, namely as many as 22 people or $24.4 \%$. This shows that on average the respondents at the Muhammadiyah University of North Sumatra are women.

Keywords: Teaching materials, Taxation, E-Invoice

\section{INTRODUCTION}

Advances in information technology have brought many positive impacts on the progress of the world of education today, it must be realized that the development of information technology has entered various aspects of life, including the world of education. In terms of learning which is currently required to be able to produce quality graduates, of course, it must look at future demands which are not only competitive but also closely related to various technological and information advances, then the quality of the learning system developed must be able to properly correct various weaknesses. which exists. One way that can be developed is to change the conventional learning system with a more effective and efficient learning system with the support of adequate facilities and infrastructure.

Classroom action research is one type of action research carried out by practicing educators in the learning process in the classroom. According to Raka Joni, et al (1998) interpret classroom action research as a form of reflective study by action actors, which is carried out to increase the rational stability of their actions in carrying out their duties, deepen understanding of the actions they take, and improve the conditions in which these learning practices are carried out. Classroom action research solves learning problems that arise in the classroom which will improve abilities and skills and will improve the quality of professionalism. Tax management is a management strategy to control, plan, and organize taxation aspects from the side that can benefit the company's business value while still carrying out tax obligations according to regulations and laws. So with the tax planning that is supported by a clear tax management concept, it is expected to optimize the company's liquidity level.

Economists believe that not all financial transfers to the public sector can be categorized as taxes. An example is some transfers to the public sector which are still influenced by prices. This is for example, tuition fees at state universities and costs for providing services to the government. Governments also obtain financial resources by "creating" money (e.g. by printing money), through grants (e.g. contributions to public universities and museums), by imposing sanctions (such as fines for traffic violations), by taking on debt, and by seizing wealth. . From an economist's point of view, tax is a non-penal transfer of resources from the private sector to the public sector which is collected on a predetermined basis and without stating the benefits to be provided. 
This study refers to students of the Faculty of Economics and Business Accounting study program who attend lectures with Taxation courses, observations and evaluations before researchers have identified problems from the student side as study participants. Learning that is followed by using a classical approach, such as lectures, discussions, questions and answers, exercises and assignments is considered monotonous, it seems that most students find taxation difficult so that students are less motivated. It can be seen again from the results of the evaluation of learning through exams, both in the middle and at the end of the semester, the scores obtained by students are low. The results of the study stated that student difficulties and failures were caused by internal and external factors including students, facilities, curriculum,

To overcome this, researchers are motivated to conduct research on the development of taxation teaching materials using the E-Faktur method as a reinforcement for taxation learning by utilizing information technology as a learning medium used by students so that the lectures become effective, each course material given to their students will compare and linking the theory discussed to practice through the use of information technology. Given that adults like practical and problem-centered learning, like learning that integrates new information with their experiences and like learning that shows individual attention (Jeperis Nahampun, 2009).

Based on this description, it is necessary to conduct research to find a comprehensive model for developing teaching materials so that the goal of adding insight and mastery of technology can be achieved optimally. Therefore, this research focuses on the development of tax practicum teaching materials using the E-Faktur method.

\section{RESEARCH METHOD}

The method used in this research is the application of the Student Team Achievment Division (STAD) cooperative learning method, the application of the accounting method and the Tax Management learning model Using the E-Faktur Method. This study uses primary and secondary data. Where primary data in the form of perceptions of students at the University of Muhammadiyah Sumatra Utara (UMSU) Faculty of Economics was obtained through the distribution of questionnaires and interviews and secondary data in the form of examples of tax financial statements presented by both manufacturing and service companies obtained by opening the website of the related company. This research uses descriptive-exploratory method

\section{RESULTS AND DISCUSSION}

\subsection{Results of Observations, Interviews Regarding Tax Management Learning Models and Characteristics of Respondents}

This research was conducted on North Sumatra Muhammadiyah University students who took the 6th semester tax management course for the 2018-2019 academic year with a research sample of 90 people.

Table 1. Overview of Respondents

\begin{tabular}{|ll|l|l|l|l|}
\hline & Frequency & Percent & Valid Percent & $\begin{array}{c}\text { Cumulative } \\
\text { Percent }\end{array}$ \\
\hline Valid & Man & 22 & 24.4 & 24.4 & 24.4 \\
& Woman & 68 & 75.6 & 75.6 & 100.0 \\
& Total & 90 & 100.0 & 100.0 & \\
\hline
\end{tabular}


Based on table 1, it can be seen that the number of female respondents was more, namely 68 people or $75.6 \%$, when compared to male respondents, namely as many as 22 people or $24.4 \%$. This shows that on average the respondents at the Muhammadiyah University of North Sumatra are women.

Table 2. Analysis of Research Variables

\begin{tabular}{|c|c|c|c|c|c|c|c|c|c|c|c|c|}
\hline \multirow[b]{2}{*}{ Statement } & \multicolumn{2}{|c|}{ SS } & \multicolumn{2}{|c|}{$S$} & \multicolumn{2}{|c|}{$\mathrm{R}$} & \multicolumn{2}{|c|}{ TS } & \multicolumn{2}{|c|}{ STS } & \multirow{2}{*}{$\begin{array}{c}\text { Average } \\
\text { score }\end{array}$} & \multirow[t]{2}{*}{ Note: } \\
\hline & $\square$ & $\%$ & $\square$ & $\%$ & $\square$ & $\%$ & $\square$ & $\%$ & $\square$ & $\%$ & & \\
\hline $\begin{array}{l}\text { Lecturers provide } \\
\text { learning materials } \\
\text { clearly }\end{array}$ & 12 & 13.3 & 27 & 30.0 & 17 & 18.9 & 2 & 2.2 & 32 & 35.6 & 2.83 & $\begin{array}{l}\text { Pretty } \\
\text { good }\end{array}$ \\
\hline $\begin{array}{l}\text { This learning } \\
\text { material is very } \\
\text { interesting }\end{array}$ & 6 & 6.7 & 26 & 28.9 & 10 & 11.1 & 14 & 15.6 & 34 & 37.8 & 2.51 & $\begin{array}{l}\text { Not } \\
\text { good }\end{array}$ \\
\hline $\begin{array}{l}\text { Lecturers provide } \\
\text { stories, pictures } \\
\text { or examples that } \\
\text { show how the } \\
\text { benefits of this } \\
\text { learning material } \\
\text { for students }\end{array}$ & 3 & 3.3 & 39 & 43.3 & 10 & 11.1 & 32 & 35.6 & 6 & 6.7 & 2.67 & $\begin{array}{l}\text { Pretty } \\
\text { good }\end{array}$ \\
\hline $\begin{array}{l}\text { This lesson is } \\
\text { very abstract so it } \\
\text { is difficult for me } \\
\text { to keep the } \\
\text { students' attention }\end{array}$ & 29 & 32.2 & 19 & 21.1 & 15 & 16.7 & 18 & 20.0 & 9 & 10.0 & 3.45 & Well \\
\hline $\begin{array}{l}\text { Lecturers provide } \\
\text { information about } \\
\text { learning materials }\end{array}$ & 33 & 36.7 & 12 & 13.3 & 32 & 35.6 & 5 & 5.6 & 8 & 8.9 & 3.63 & Well \\
\hline $\begin{array}{l}\text { At the beginning } \\
\text { of learning, the } \\
\text { lecturer gives } \\
\text { something } \\
\text { interesting for } \\
\text { students }\end{array}$ & 5 & 5.6 & 20 & 22.2 & 26 & 28.9 & 9 & 10.0 & 30 & 33.3 & 2.56 & $\begin{array}{l}\text { Not } \\
\text { good }\end{array}$ \\
\hline
\end{tabular}

Based on table 2, it can be seen that the statement about the lecturer providing learning material clearly is 2.83 , which means that it is in the fairly good category. The learning material that attracts attention is 2.51 , which means it is in the bad category. The lecturer provides stories, pictures or examples that show how the benefits of this learning material for students are 2.67, which means that they are in the fairly good category. This learning is very abstract so it is difficult for me to keep the students' attention is 3.45 , is in the good category. For questions to the lecturer providing information about the learning material is 3.63 , is in the good category. Meanwhile, at 
the beginning of the lesson, the lecturer gave something interesting to the students, which was 2.56 , which was in the bad category.

\subsection{Tax Management Learning}

From this study, by looking at the learning motivation of students with good categories, it is divided into 2 statement items, namely this learning is very abstract so it is difficult for me to keep the attention of students and lecturers providing information about learning materials, because motivation will not grow in students if students do not have a strong determination and desire. So, as a lecturer, it is necessary to have a better teaching method by providing better material so that the students' enthusiasm and motivation to learn will increase. Meanwhile, the student learning activities have been good, but there are several things in the learning activities that must be improved, namely in terms of preparing the syllabus as a reference in the development of lecture designs that include the identity of the courses or lecture themes, making a learning implementation plan (RPP) which is described from the syllabus. to direct student learning activities in an effort to achieve basic competencies. On the other hand, from learning outcomes, it can be seen that to see student learning outcomes, lecturers can see three factors, namely internal factors including intelligence, attitudes, talents, interests, motivation and personality. make a learning implementation plan (RPP) which is described from the syllabus to direct student learning activities in an effort to achieve basic competencies. On the other hand, from learning outcomes, it can be seen that to see student learning outcomes, lecturers can see three factors, namely internal factors including intelligence, attitudes, talents, interests, motivation and personality. make a learning implementation plan (RPP) which is described from the syllabus to direct student learning activities in an effort to achieve basic competencies. On the other hand, from learning outcomes, it can be seen that to see student learning outcomes, lecturers can see three factors, namely internal factors including intelligence, attitudes, talents, interests, motivation and personality.

\subsection{E-Invoice Method}

E-Tax invoices are tax invoices made or electronic systems determined and/or provided by the Directorate General of Taxes. Computer operating systems that can be used to run efaktur are windows, linux and mac. E-tax invoices began to be used for the first time on July 1, 2014 which at that time was tested on as many as 45 PKPs, then followed on July 1, 2015 for all PKPs in Java and Bali, since July 1, 2016 e-invoices have been required for all PKP throughout Indonesia.

\section{CONCLUSION}

From the research conducted, the following results were found: 1) In general, the learning conditions for Tax Management were good, but development was needed in terms of learning models. 2) The appropriate method used is the contextual method. 3) The components of the Tax Management learning curriculum must be adapted to the needs of the business world. 4) Textbooks used as guidelines in learning need to be adapted to the needs of the world of education. From the results of this study, suggestions can be given, firstly, it is necessary to have an understanding of the lecturers' characteristics of the students being taught, so that they are able to carry out learning innovations. 


\section{REFERENCE}

Darmadi, Hamid. 2011. Basic Concept of Moral Education. Bandung : Alphabeta

Directorate General of Taxes, Law no. 28 of 2007 concerning General Provisions and Tax Procedures.

Endang Komara, 2011.http://www.geocities.ws/endangkumara/, Learning Strategies in Higher Education. Univ. Padjadjaran Bandung

Hamzah B. Uno, 2010, H, Learning Models, Creating an Effective Teaching and Learning Process, Jakarta, Bumi Aksara

Mardiasmo, Taxation, 2008, Andi Jogjakarta Publisher

Mukh. Arifin, 2010. eeda Journey. Change the Learning Model in Higher Education. Semarang: November.

Pohan, Chairil Anwar, Tax Management, Gramedia, 2017

Republic of Indonesia. (2013). Law Number 20 of 2003 concerning the National Education System. Jakarta: Kloang klede Putra Timur

Sagala, Syaiful.2011. The Concept and Meaning of Learning. Bandung: Alphabeta

Sagala, Syaiful. 2011. Contemporary Education Administration. Bandung: Alphabeta

Official Siti, Taxation, Theory and Cases, 2011, Salemba Empat Publishers

Suharsimi A. 2013. Research Procedure A Practical Approach. Jakarta: Rineka Cipta

Suwardjono. 2012. Revolution of Higher Education Learning Paradigm: from Lecture to Learning. Materials for debriefing at a local seminar at the Faculty of Economics and Business, Gajah Mada University, Yogyakarta.

The Big Indonesian Dictionary Compilation Team..2012. Indonesia Dictionary. Jakarta: Balai Pustaka

Waluyo, Indonesian Taxation, 2010, Salemba Empat Publishers

Winarno Surakhmad. 2012. Introduction to Scientific Research, basics, methods, and techniques. Bandung: Transito

Zaaini, Hisham., Bermawy Munthe, and Sekar Ayu Aryani. 2012. Active Learning Strategies in Higher Education. Yogyakarta: CTSD.

Zulia Hanum, et al. 2018. Model for Development of Teaching Materials for Lecture on Tax Accounting with Computer Tax Programs.

Zulia Hanum, et al. 2018. Development Model of Tax Accounting Lecture Teaching Materials With Tax Computer Program.

Zulia Hanum, et al. 2018. Introduction to Taxation Easy Ways to Calculate Taxes. Medan : Perdana Publishing. 